\title{
Environmental performance analysis for the construction phase of building projects by using the indicators recommended by PBQP-H
}

\author{
Análise do desempenho ambiental da fase de construção \\ de projetos de edificações a partir dos indicadores \\ recomendados pelo PBQP-H
}

\section{Luara Lopes de Araujo Fernandes Dayana Bastos Costa}

\begin{abstract}
$\mathbf{T}$ he construction industry uses certain performance indicators to monitor the impacts generated by their associated activities. However, the strict determination of these indicators cannot enhance the performance of a company, and certain benchmarks must be established to guide the goals and evaluate the performance of the companies. Therefore, this study aims to evaluate the scenario and evolution of the environmental performance of the construction phase of building projects by using the indicators recommended by the Brazilian Program for Quality and Productivity in Habitat (PBQP-H) and to establish benchmarks for these indicators. The research strategy adopted in this study corresponded to a survey with 186 building projects. The results involved environmental performance scenario of the building sector in different scopes. The main contribution of this study is the establishment of a set of parameters and benchmarks that can help enhance the performance of the building construction sector. As practical implication, the presented analysis and trends may provide guidance to governments and sectoral initiatives to formulate public policies to enhance the environmental performance of the sector.
\end{abstract}

Keywords: Environmental performance. Construction. Indicators. Sustainability. Benchmarking.

\section{Resumo}

A indústria da construção usa indicadores de desempenho para monitorar os impactos gerados pelas suas atividades. Entretanto, apenas a coleta de indicadores não promove melhoria de desempenho e as empresas precisam de valores de referência para embasar suas metas e avaliar seu desempenho. Assim, o objetivo deste estudo é avaliar o cenário e a evolução do desempenho ambiental da fase de construção de projetos de edificações, baseado nos indicadores recomendados pelo PBQP-H (Programa Brasileiro de Qualidade e Produtividade no Habitat), bem como estabelecer valores de referência para esses indicadores. A estratégia de pesquisa adotada foi o levantamento de

${ }^{1}$ Luara Lopes de Araujo Fernandes 'Universidade Federal da Bahia Salvador - Bahia - Brasil

${ }^{2}$ Dayana Bastos Costa 2Universidade Federal da Bahia Salvador - Bahia - Brasil

Recebido em 25/05/20 Aceito em 26/01/21 dados (survey) em 186 projetos de edificação. Os resultados envolveram a análise do cenário do desempenho ambiental do setor de edificações em diferentes escopos. A principal contribuição desse estudo é o estabelecimento de um conjunto de parâmetros e valores de referência para melhorar o desempenho ambiental do setor da construção civil. Como implicação prática, as análises e tendências identificadas ao longo deste trabalho podem orientar governos e iniciativas setoriais para propor políticas públicas para melhorar o desempenho ambiental do setor.

Palavras-chave: Desempenho ambiental. Construção. Indicadores. Sustentabilidade. Benchmarking.

FERNANDES, L. L. de A.; COSTA, D. B. Environmental performance analysis for the construction phase of building projects by using the indicators recommended by PBQP-H. Ambiente Construído, Porto Alegre, v. 21, n. 3, p. 7-26, jul./set. 2021. 


\section{Introduction}

Due to the increasing demand, the shift toward performance based approaches, and related sustainability issues, the industrial sector is pursuing more integrative solutions (ILHAN; YOBAS, 2019). In terms of sustainable development, indicators represent the key components of the three pillar approach (environment, economic, and social), providing usable and pertinent information (WALLBAUM, 2008). A corporate sustainability assessment can help identify the strengths and weaknesses in an organization's development through the analysis of the interrelations of the indicator and final sustainability performance (JIANG et al., 2018).

The increased demand to incorporate sustainability in the company processes for the entire lifecycle of the products made performance assessment necessary (NAPPI; ROZENFELD, 2015). Lopes and Sanchez (2011) developed different methods to satisfy a sustainability value by integrating multiple indicators. In general, performance evaluation is a key decision tool for managers (REZAEI; ÇELIK; BAALOUSHA, 2011). This process provides the information required to evaluate if an organization delivers value and can achieve excellence (MOULLIN, 2007) by using tools and instruments to measure the criteria required for continuous assessment and improvement. A performance measurement system is composed of a series of measures (or indicators) used to quantify the efficiency or effectiveness of a process (NEELY et al., 1997).

In the construction industry, efforts have been focused at the institutional level to develop methodologies and establish guidelines to perform environmental assessment. The United Kingdom government has developed guidelines and key performance indicators focused on business, encompassing the indicators related to emissions and pollution, water, biodiversity, materials, and waste. The Constructing Excellence organization, also from the UK, annually publishes reference values for the indicators associated with the construction industry, including environmental indicators for water and energy consumption, waste, and commercial vehicle mobility. The Construction Industry Institute (CII) from the USA has established a set of performance measures for the construction industry, encompassing sustainability indicators related to waste management, number of neighborhood complaints, size of the ecological footprint, and percentage of projects involving sustainable development.

In Brazil, since 2012, the Brazilian Program for Quality and Productivity in Habitat (PBQP-H), through its Quality System Certification Program (System for Conformity Evaluation - SIAC), has recommended the collection of six sustainability indicators during and at the end of the construction phase for internal purposes. The indicators correspond only the environmental aspect of sustainability and evaluate the water consumption, energy consumption, and waste generation. In its recent update (2018), the SIAC regulation removed the indicators measured during the construction, and at present, only the indicators at the end of the construction are required to be measured.

Nevertheless, despite their importance in the social, economic, and environmental decision making processes, considering only the indicators cannot help enhance the performance (SILVA, 2003). A key objective of performance measurement is to enable a company to implement benchmarking (COSTA et al., 2006). Performance targets and reference performance values for each indicator are necessary to determine the performance scale and assess the progress (SILVA, 2003). Benchmarking aims at facilitating a comparison of the performance of different firms, thereby providing the organizations the opportunity to recognize their weaknesses and strengths, using the industry values as a reference (EL-MASHALEH; MINCHIN JUNIOR; O’BRIEN, 2007).

Therefore, this study is aimed at evaluating the scenario and evolution of the environmental performance of the construction phase of building projects based on the indicators recommended by the PBQP-H, providing reference values for construction companies and projects to compare and improve their performance.

To this end, data were analyzed to obtain the descriptive statistics for the global sample. Moreover, the evolution process was analyzed considering the year, type of construction system (reinforced concrete structure, cast-in-place reinforced concrete wall, and masonry structure), and construction progress scope.

The primary hypotheses established and tested in this study, through two nonparametric statistics tests (Mann-Whitney and Kruskal-Wallis), were as follows:

(a) the type of construction system influences the water consumption, energy consumption, and waste generation during construction; and

(b) the construction progress scope influences the water consumption, energy consumption, and waste generation during construction. 
The secondary hypotheses tested to identify and analyze the causes for the obtained outcomes were as follows:

(a) the construction duration influences the water consumption, energy consumption, and waste generation during construction;

(b) the built area influences the water consumption, energy consumption, and waste generation during construction; and

(c) the use of load vertical transportation equipment influences the energy consumption during construction.

\section{Background}

In general, the criteria of environmental assessment methodologies are focused on the operation phase of buildings, as it is the largest phase. Although the contribution of the construction phase is small compared to the entire life cycle of a building, this phase cannot be neglected because of its negative impact on the environment due to the excessive resource consumption (ORTIZ; PASQUALINO; CASTELLS, 2010).

In the past ten years, several studies have presented strategies and methodologies to reduce the environmental impact corresponding to the construction site processes. Oliveira (2011) developed a model to assess and classify the environmental sustainability in construction sites. Fuertes et al. (2013) proposed a model to clarify the environmental aspects and impacts related to the construction process, focusing on construction site elements, such as the material, machinery, workers, and workplace aspects. Guimarães (2013) proposed guidelines for the development of low impact construction sites. Gangolells et al. (2014) analyzed the implementation of the waste management practices in the construction process, adopted by construction companies and other stakeholders in the sector during the design, planning, and execution phases. Thomas and Costa (2017) established a set of criteria pertaining to the adoption of sustainable management practices in construction sites to mitigate the environmental impacts corresponding to the construction phase. Almeida, Costa and Alberte (2020) developed a system of indicators for sustainable management in construction sites (SIGS), composed of 26 indicators that covered the environmental, social, and economic dimensions.

Such guidelines and sustainability performance indicators provide support to realize sustainability management, measurement, and reporting (SHAHBAZI et al., 2018). In the construction domain, sustainability indicators allow the description of environmental, social, and economic impacts of buildings (SILVA, 2007; LÓPEZ; SÁNCHEZ, 2011). According to Silva (2007), the sustainability indicators in the construction domain can be categorized as follows:

(a) national indicators, which can correspond to environmental or sustainable development aspects;

(b) sectorial indicators, which are focused on one sector, such as building construction;

(c) organizational indicators, which are related to firms, projects and constructions; and

(d) building and project indicators, which are specific.

The existing literature reports on certain national initiatives aimed at recommending environmental indicators for the construction sector, focusing on the water consumption, energy consumption, and waste generation (Table 1).

Different databases, assessment methods, and software tools aim to quantify the environmental impacts of different activities; however, no consensus exists yet regarding the metric to be used and method to report the results (HOFFENSON; DAGMAN; SODERBERG, 2013). Different countries consider different definitions and measures for the construction activity; therefore, the aforementioned initiatives cannot be benchmarked because the adopted metrics are considerably different. As stated by Ilhan and Yobas (2019), it is necessary to establish a standard international measure for the construction activity.

\section{Research method}

The research strategy adopted in this study was a survey, which was aimed at collecting a large number of project indicator data to evaluate the scenario and evolution of the environmental performance of the construction phase of building projects. Figure 1 presents the research design. 
Table 1 - Environmental indicators associated with the water, energy, and waste aspects in international initiatives

\begin{tabular}{|c|c|c|c|c|}
\hline Country & Name/initiative & Indicator & Metrics & Source \\
\hline \multirow{3}{*}{$\begin{array}{l}\text { United } \\
\text { Kingdom }\end{array}$} & \multirow{3}{*}{ KPI } & Energy & $\begin{array}{l}\text { Median energy use } \mathrm{kg} \mathrm{CO}_{2} / \\
£ 100 \mathrm{k} \text { project value }\end{array}$ & \multirow{3}{*}{$\begin{array}{l}\text { Constructing } \\
\text { Excellence (2016) }\end{array}$} \\
\hline & & Water & $\begin{array}{l}\text { Median water use } \mathrm{m}^{3} / £ 100 \mathrm{k} \\
\text { project value }\end{array}$ & \\
\hline & & Waste & $\begin{array}{l}\text { Median waste removed from } \\
\text { site } \mathrm{m}^{3} / £ 100 \mathrm{k} \text { project value }\end{array}$ & \\
\hline \multirow[b]{2}{*}{ Hong Kong } & \multirow{2}{*}{$\begin{array}{l}\text { Construction } \\
\text { Industry Council }\end{array}$} & Waste & $\begin{array}{l}\text { Construction waste } \div \\
\text { Construction GDP }\end{array}$ & $\begin{array}{l}\text { Hastak et al. } \\
\text { (2017) }\end{array}$ \\
\hline & & Energy & $\begin{array}{l}\text { Consumption of energy and } \\
\text { resources } \div \text { Gross value of } \\
\text { construction }\end{array}$ & $\begin{array}{l}\text { Hastak et al. } \\
(2017)\end{array}$ \\
\hline Canada & GBTool & $\begin{array}{l}\text { Solid waste from } \\
\text { construction and } \\
\text { demolition processes }\end{array}$ & 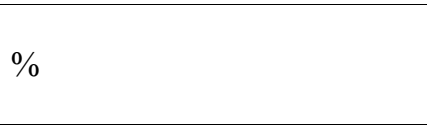 & \multirow{2}{*}{ Australia (2005) } \\
\hline Australia & EPGB & Waste & $\begin{array}{l}\% \\
\mathrm{t}, \% \\
\mathrm{~m}, \text { whole structure }\end{array}$ & \\
\hline \multirow{3}{*}{$\begin{array}{l}\text { Nordic } \\
\text { countries }\end{array}$} & \multirow{3}{*}{ Nordic project } & Waste & $\mathrm{kg} / \mathrm{m}^{2}$ or $\mathrm{kg} /$ person, $\mathrm{y}$ & \multirow{3}{*}{$\begin{array}{l}\text { Sigurjónsson et } \\
\text { al. (2002) }\end{array}$} \\
\hline & & Energy & $\mathrm{KWh} / \mathrm{m}^{2}, \mathrm{y}$ & \\
\hline & & Water & $\mathrm{m}^{3} / \mathrm{m}^{2}, \mathrm{y}$ & \\
\hline \multirow{3}{*}{ Brazil } & \multirow{3}{*}{ PBQP-H } & Water & $\mathrm{m} / \mathrm{m}$ & \multirow{3}{*}{$\begin{array}{l}\text { Ministério das } \\
\text { Cidades (2018) }\end{array}$} \\
\hline & & Energy & $\mathrm{kWh} / \mathrm{m}$ & \\
\hline & & Waste & $\mathrm{m} / \mathrm{m}$ & \\
\hline
\end{tabular}

Figure 1 - Research design

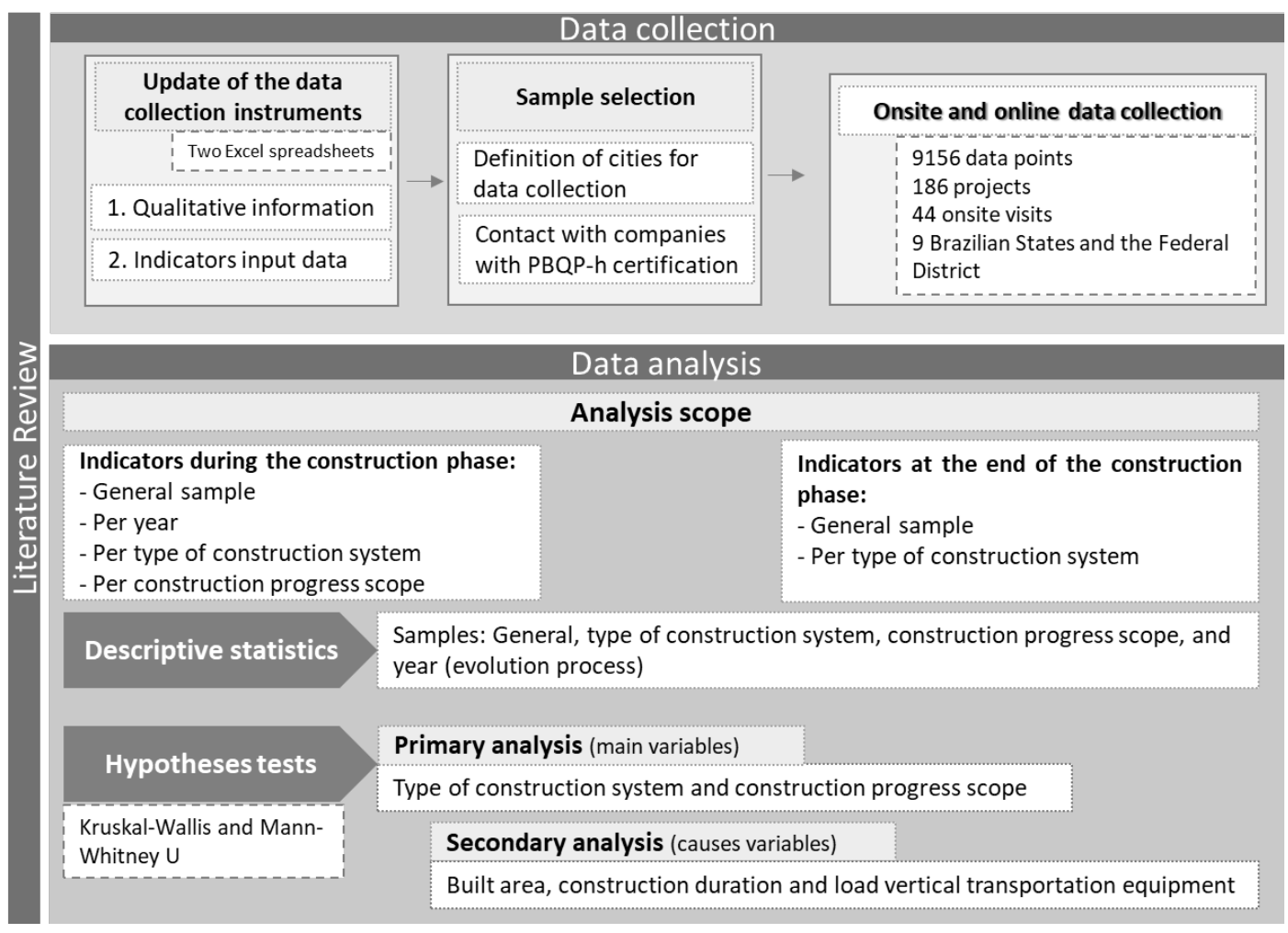

10 Fernandes, L. L. de A.; Costa, D. B. 
In the literature review phase, the main topics related to the sustainable management and performance measurement focused on the construction phase were examined to provide the appropriate background for the subsequent phases of the study.

The following PBQP-H indicators were used for the analysis:

(a) energy consumption during the construction ( $\mathrm{kWh} /$ number of workers);

(b) energy consumption at the end of the construction $(\mathrm{kWh} / \mathrm{m})$;

(c) waste generation during the construction ( $\mathrm{m} /$ number of workers);

(d) waste generation at the end of the construction $(\mathrm{m} / \mathrm{m})$;

(e) water consumption during the construction ( $\mathrm{m} /$ number of workers); and

(f) water consumption at the end of the construction $(\mathrm{m} / \mathrm{m})$.

Although the PBQP-H eliminated the indicators during the construction from the mandatory list in 2018, these indicators are considered in this study to analyze the impact of the entire construction process. Figure 1 presents the research design.

\section{Data collection}

In the data collection phase, first, the spreadsheets created in a previous work (ALMEIDA; COSTA; ALBERTE, 2020) were updated. Thus, the data collection instruments used in this study involved two Excel spreadsheets:

(a) the first sheet corresponded to the qualitative information regarding the construction site (construction system, building purpose, target public, and alternative use of water and energy); and

(b) the second one corresponded to the data of the indicators and information related to the construction progress and phase.

The data were acquired through onsite and online collection. The onsite data collection was performed in the construction companies' headquarters or construction projects in 5 Brazilian capital states and metropolitan areas (Salvador, Fortaleza, Goiania, Porto Alegre, and Campinas) and Brasilia (the Federal District). The selection of these states for the onsite data collection was based on the available financial resources and support of the university partners. The sample selection required the identification of the companies certified by the SIAC-PBQP-H program in the selected locations.

Subsequently, the research team invited the companies to participate in the study. Data were collected from March to August 2019, and throughout 2019 in the city of Salvador (Table 2).

Several construction companies preferred to send the data by email. Moreover, three companies that the team visited during the onsite data collection shared data from four other states that were not previously selected (Sergipe, Alagoas, Pernambuco, and Paraná).

\section{Sample characterization}

The total data included 9,156 data points from 186 building projects in Brazil (Table 3). The sample involved the following scenarios: $42 \%, 23 \%, 29 \%$ and $6 \%$ of the construction projects were located in the northeast region, midwest region, southern region, and southeast (all projects located in the São Paulo State) region of Brazil, respectively. The northeast region was the researchers' region of residency, which facilitated the interaction with managers and, thus, the data collection.

The sample was not stratified by location (state or region) for the analyses. A previous investigation indicated that the differences among the building projects in different locations were related to the type of construction system of the project and not to the local variables. 
Table 2 - Onsite data collection calendar

\begin{tabular}{l|l|l|c|c}
\hline \multicolumn{1}{c|}{ City } & \multicolumn{1}{c|}{ State } & \multicolumn{1}{c|}{ Region } & \multicolumn{1}{c}{ Period } & $\begin{array}{c}\text { Number of data } \\
\text { collection visits }\end{array}$ \\
\hline Fortaleza & Ceará & Northeast & $11 / 03 / 2019-15 / 03 / 2019$ & 8 \\
Brasília & Federal District & Midwest & $25 / 03 / 2019-27 / 03 / 2019$ & 6 \\
Goiânia & Goiás & Midwest & $28 / 03 / 2019-29 / 03 / 2019$ & 8 \\
Porto Alegre & Rio Grande do Sul & South & $22 / 04 / 2019-26 / 04 / 2019$ & 8 \\
Campinas & São Paulo & Southeast & $19 / 08 / 2019-22 / 08 / 2019$ & 2 \\
Salvador & Bahia & Northeast & During 2019 & 12 \\
\hline \multicolumn{3}{l}{ Total visits } & & 44 \\
\hline
\end{tabular}

Table 3 - Sample of the considered construction companies and projects

\begin{tabular}{l|l|c|c|c}
\hline Region & States & $\begin{array}{c}\text { Number of } \\
\text { construction } \\
\text { companies }\end{array}$ & $\begin{array}{c}\text { Number of } \\
\text { building } \\
\text { projects }\end{array}$ & $\begin{array}{c}\text { \% of building } \\
\text { projects } \\
\text { among all } \\
\text { projects }\end{array}$ \\
\hline \multirow{5}{*}{ Northeast } & Bahia & 8 & 37 & 19.9 \\
& Ceará & 6 & 22 & 11.8 \\
& Alagoas & 1 & 6 & 3.3 \\
& Sergipe & 1 & 3 & 1.6 \\
\multirow{2}{*}{ Midwest } & Pernambuco & 2 & 10 & 5.4 \\
\hline Southeast & Gistrito Federal & 3 & 8 & 4.3 \\
\hline \multirow{2}{*}{ South } & São Paulo & 9 & 35 & 18.8 \\
\hline Total & Rio Grande do Sul & 6 & 12 & 6.4 \\
\hline
\end{tabular}

Table 4 presents the number of building projects collected for each indicator. It must be noted that even though the total amount of considered projects was 186, not all the projects provided the data for all the indicators. The indicators during the construction constituted the major proportion of the data because most of the building projects of the sample were under development. Moreover, companies generally discard the indicator data when a building project is finished and delivered to the client, which justifies the small number of indicators corresponding to the end of the construction. Furthermore, the project personnel introduced certain data collection errors and inconsistencies, owing to which the collected data was invalidated or lost, as reflected in the variations in the number of indicators for each project.

In terms of the building market, $89 \%$ and $7 \%$ of the projects corresponded to residential and commercial buildings, respectively, and data for $4 \%$ were not available. In terms of the type of construction systems, $49 \%, 35 \%, 14 \%$ and $2 \%$ of the projects corresponded to reinforced concrete structures, cast-in-place reinforced concrete walls, structural masonry, and precast concrete structures, respectively. The analysis corresponding to the type of construction system did not consider precast concrete construction sites, because the sample was extremely small and was thus not representative.

The monthly average number of workers in the sample was 112, 105, 90, and 91 for reinforced concrete structures, cast-in-place reinforced concrete walls, structural masonry, and precast concrete structures, respectively.

Approximately $37.63 \%$ (70 building projects) of the total sample provided information regarding the construction progress, associated with the indicators during the construction. In the sample, 56\%, 30\%, $11 \%$ and $3 \%$ of the projects used cast-in-place reinforced concrete wall systems, reinforced concrete structures, structural masonry, and precast concrete structures, respectively. Moreover, $93 \%$ and $7 \%$ of the projects were residential and commercial, respectively. 
Table 4 - Sample for each environmental indicator $(\mathrm{N}=186)$

\begin{tabular}{c|c|c|c|c|c|c}
\hline \multirow{2}{*}{} & \multicolumn{2}{|c|}{ Indicators during the construction } & \multicolumn{2}{c}{$\begin{array}{c}\text { Indicators at the end of the } \\
\text { construction }\end{array}$} \\
\cline { 2 - 7 } & $\begin{array}{c}\text { Water } \\
\text { consumption } \\
\left(\mathbf{m}^{3} / \mathbf{n u m b e r} \text { of }\right. \\
\text { workers })\end{array}$ & $\begin{array}{c}\text { Energy } \\
\text { consumption } \\
(\mathbf{k W h} / \text { number } \\
\text { of workers })\end{array}$ & $\begin{array}{c}\text { Waste } \\
\text { generation } \\
\left(\mathbf{m}^{3} / \text { number }\right. \\
\text { of workers })\end{array}$ & $\begin{array}{c}\text { Water } \\
\text { consumption } \\
\left(\mathbf{m}^{3} / \mathbf{m}^{2}\right)\end{array}$ & $\begin{array}{c}\text { Energy } \\
\text { consumption } \\
\left(\mathbf{k W h} / \mathbf{m}^{2}\right)\end{array}$ & $\begin{array}{c}\text { Waste } \\
\text { generation } \\
\left(\mathbf{m}^{3} / \mathbf{m}^{2}\right)\end{array}$ \\
\hline $\begin{array}{c}\text { Number of } \\
\text { projects }\end{array}$ & 161 & 160 & 142 & 80 & 78 & 63 \\
\hline
\end{tabular}

\section{Data analysis}

The first step of analysis involved obtaining the descriptive statistics for the global sample, evolution process per year, type of construction system, and construction progress scope. Moreover, the building projects that corresponded to the minimum and maximum values of the indicators were identified, and the possible causes were analyzed (based on the characterization of each project), to identify the possible disturbances that could lead to a certain increase or decrease in the indicator.

The second step involved testing the hypotheses of the study, correlating the six indicators and five variables, according to Table 5. The hypotheses were analyzed through nonparametric tests because the data did not present a Gaussian (normal) distribution, and nonparametric tests do not require the consideration of a specific distribution and can be used in a sample with multiple outliers. Only the outliers identified (and confirmed) as errors (in calculating the indicator or filling the spreadsheet) were removed because the construction process varies among different building projects. The tests were performed using the SPSS statistics software, and the significance level was set as $\alpha=5 \%$ for all the analyses.

Two nonparametric hypotheses tests, Mann-Whitney U and Kruskal-Wallis, were performed. In particular, the Mann-Whitney U test assesses if two groups are different for a single continuous variable, that is, if the two groups belong to the same population (MCKIGHT; NAJAB, 2010a). The null hypothesis (H0) indicates that the groups are from the same population, and the alternative hypothesis indicates that the distribution of the first group is different from that of the second group (NACHAR, 2008).

The Kruskal-Wallis test assesses the difference between three or more groups of the independent samples of a single continuous variable (MCKIGHT; NAJAB, 2010b). According to Chan and Walmsley (1997), this test addresses the following questions:

(a) Are the three samples different or do the differences in the results reflect the expected variations of the random samples of the same population? and

(b) Are the differences in the results genuine or coincidental?

The variables were selected to examine a specific scenario for the environmental performance of the construction phase of building projects. The data with similar characteristics were stratified and grouped, and it was examined whether the different groups had the same kind of environmental impact (related to the water consumption, energy consumption, and waste generation).

The type of construction system was considered a variable in this study because the sample involved a large proportion of building projects for the three types of construction systems. These systems have different construction processes, and thus, the resulting impact may be considerably different as well. In addition, different construction phases involve different kinds of activities, which may result in different impacts, and thus, the construction progress was considered to be the second variable.

Based on the outcomes of the first two variables (type of construction system and construction progress scope), the built area, construction duration, and use of load vertical transportation equipment were examined to better analyze the causes for the results.

Table 6 describes all the performed tests. For both the tests and all the samples, the null (H0) and alternative (H1) hypothesis corresponded to the following definitions:

(a) H0: No significant difference exists among the groups; and

(b) H1: A significant difference exists among the groups. 
Table 5 - Analyses performed for the different indicators considering the variables

\begin{tabular}{|c|c|c|c|c|c|c|c|}
\hline \multirow[t]{2}{*}{ Environmental Indicator } & \multicolumn{3}{|c|}{$\begin{array}{c}\text { Type of } \\
\text { construction } \\
\text { system }\end{array}$} & \multirow[t]{2}{*}{$\begin{array}{l}\text { Construction } \\
\text { progress } \\
\text { scope }\end{array}$} & \multirow[t]{2}{*}{$\begin{array}{l}\text { Built } \\
\text { area }\end{array}$} & \multirow[t]{2}{*}{$\begin{array}{c}\text { Construction } \\
\text { duration }\end{array}$} & \multirow[t]{2}{*}{$\begin{array}{c}\text { Load vertical } \\
\text { transportation } \\
\text { equipment }\end{array}$} \\
\hline & RC & CW & $\mathbf{S M}$ & & & & \\
\hline $\begin{array}{l}\text { Water consumption during the } \\
\text { construction }\end{array}$ & $\mathrm{x}$ & $\mathrm{x}$ & $\mathrm{x}$ & $\mathrm{x}$ & $\mathrm{x}$ & $\mathrm{x}$ & - \\
\hline $\begin{array}{l}\text { Energy consumption during } \\
\text { the construction }\end{array}$ & $\mathrm{x}$ & $\mathrm{x}$ & $\mathrm{x}$ & $\mathrm{x}$ & $\mathrm{x}$ & $\mathrm{x}$ & $\mathrm{x}$ \\
\hline $\begin{array}{l}\text { Waste generation during the } \\
\text { construction }\end{array}$ & $\mathrm{x}$ & $\mathrm{X}$ & $\mathrm{x}$ & $\mathrm{x}$ & $\mathrm{x}$ & $\mathrm{x}$ & - \\
\hline $\begin{array}{l}\text { Water consumption at the end } \\
\text { of the construction }\end{array}$ & $\mathrm{x}$ & $\mathrm{X}$ & $\mathrm{X}$ & - & - & $\mathrm{x}$ & - \\
\hline $\begin{array}{l}\text { Energy consumption at the } \\
\text { end of the construction }\end{array}$ & $\mathrm{x}$ & $\mathrm{x}$ & $\mathrm{x}$ & - & - & $\mathrm{x}$ & $\mathrm{x}$ \\
\hline $\begin{array}{l}\text { Waste generation at the end of } \\
\text { the construction }\end{array}$ & $\mathrm{x}$ & $\mathrm{x}$ & $\mathrm{x}$ & - & - & $\mathrm{x}$ & - \\
\hline
\end{tabular}

Note:

$\mathrm{RC}=$ Reinforced concrete structure;

$\mathrm{CW}=$ Cast-in-place reinforced concrete wall; and

$\mathrm{SM}=$ Structural masonry.

Table 6 - Variables and groups examined in the study

\begin{tabular}{|c|c|c|c|c|}
\hline Variable & & Group & Group characterization & Test \\
\hline \multirow{3}{*}{$\begin{array}{l}\text { Type of } \\
\text { construction } \\
\text { system }\end{array}$} & 0 & Reinforced concrete & \multirow{3}{*}{ Adopted construction system } & \multirow{3}{*}{$\begin{array}{c}\text { Kruskal-Wallis and } \\
\text { Mann-Whitney U }\end{array}$} \\
\hline & 1 & Concrete wall & & \\
\hline & 2 & Structural masonry & & \\
\hline \multirow{10}{*}{$\begin{array}{l}\text { Construction } \\
\text { progress } \\
\text { scope }\end{array}$} & 0 & $0-10 \%$ & \multirow{10}{*}{ Range of $10 \%$ of progress } & \multirow{10}{*}{ Kruskal-Wallis } \\
\hline & 1 & $10-20 \%$ & & \\
\hline & 2 & $20-30 \%$ & & \\
\hline & 3 & $30-40 \%$ & & \\
\hline & 4 & $40-50 \%$ & & \\
\hline & 5 & $50-60 \%$ & & \\
\hline & 6 & $60-70 \%$ & & \\
\hline & 7 & $70-80 \%$ & & \\
\hline & 8 & $80-90 \%$ & & \\
\hline & 9 & $90-100 \%$ & & \\
\hline \multirow{5}{*}{ Built area } & 0 & 0-9999 & \multirow{5}{*}{$\mathrm{m}$ of built area } & \multirow{5}{*}{ Kruskal-Wallis } \\
\hline & 1 & $10.000-19.999$ & & \\
\hline & 2 & $20.000-29.999$ & & \\
\hline & 3 & $30.000-39.999$ & & \\
\hline & 4 & $40.000-\infty$ & & \\
\hline \multirow{4}{*}{$\begin{array}{l}\text { Construction } \\
\text { duration }\end{array}$} & 0 & $0-12$ & \multirow{4}{*}{ Duration in months } & \multirow{4}{*}{ Kruskal-Wallis } \\
\hline & 1 & $12-24$ & & \\
\hline & 2 & $24-36$ & & \\
\hline & 3 & $36-\infty$ & & \\
\hline \multirow{2}{*}{$\begin{array}{l}\text { Load vertical } \\
\text { transportation } \\
\text { equipment }\end{array}$} & 0 & Used & \multirow{2}{*}{$\begin{array}{l}\text { Load vertical transportation } \\
\text { equipment used/not used }\end{array}$} & \multirow{2}{*}{ Mann-Whitney U } \\
\hline & 1 & Not used & & \\
\hline
\end{tabular}

The correlation among the indicators was analyzed by Fernandes, Rocha and Costa (2020). The authors applied the clustering technique to identify if the type of construction system as a project characteristic influenced the kind of environmental impact caused by the building projects in the construction phase. The results indicated that, even in the case of different indicators metrics, the building projects were mostly grouped by the type of construction system, indicating that the indicators may be correlated, and this characteristic may influence the environmental impact.

14 Fernandes, L. L. de A.; Costa, D. B. 


\section{Findings}

This section presents the findings pertaining to the descriptive statistics analysis of the sample, evolution of the indicators during the construction each year and analyses according to the type of construction system and construction progress scope.

\section{Descriptive statistics analysis}

Table 7 presents the descriptive statistics analysis for the examined six indicators, obtained considering the sample of 186 building projects and the specific sample for each indicator.

The variance coefficient presented a high variability in terms of the mean data for all the indicators. The indicator of the waste generation during the construction has the highest value (532\%). The data asymmetry highlights that all the samples had a positive asymmetry, indicating a high concentration of low values. However, the high values led to an increase in the mean value. This data variability and asymmetry can be attributed to the high complexity and variability of the construction site activities. Thus, to reduce the influence of the complexity and variability, the reference values adopted for this study were the medians of each sample. The medians related to the whole sample were termed as the global median and used for the comparison in the subsequent analyses.

Table 8 presents the building projects corresponding to the minimum and maximum values associated with each indicator, to identify the differences among the projects with the best and worst outcomes, respectively, and the causes for the results. In this case, the analysis was limited to the building projects for which the qualitative information was available in the characterization spreadsheet. For the indicators during the construction, the median value for the months is considered to ensure that the variability of an isolated month does not influence the result of the entire building project. The measured values were considered for the indicators at the end of the construction.

\section{Evolution of the indicators during the construction in different years}

This analysis was aimed at evaluating the impact of the indicators in the process of improving the environmental performance of the building projects. However, it was not possible to analyze the indicators at the end of the construction, because a large amount of the data was extracted from the companies' databases, and most of the data did not provide the qualitative information requested, such as the year of the end of the construction. It is worth mentioning that the 2019 indicators were collected until August of that year. Therefore, that median may be different if the values of the following months are added to the sample.

Table 7 - Descriptive statistics analysis of the six environmental indicators $\left(N_{\text {total }}=186\right)$

\begin{tabular}{|c|c|c|c|c|c|c|}
\hline \multirow[b]{2}{*}{ Parameter } & \multicolumn{3}{|c|}{ Indicators during the construction } & \multicolumn{3}{|c|}{ Indicators at the end of the construction } \\
\hline & $\begin{array}{c}\text { Water } \\
\text { consumption } \\
\left(\mathbf{m}^{3} / \text { number of }\right. \\
\text { workers) } \\
(\mathrm{N}=161) \\
\end{array}$ & $\begin{array}{c}\text { Energy } \\
\text { consumption } \\
(\mathbf{k W h} / \text { number } \\
\text { of workers) } \\
(\mathrm{N}=\mathbf{1 6 0}) \\
\end{array}$ & $\begin{array}{c}\text { Waste } \\
\text { generation } \\
\left(\mathbf{m}^{3} / \text { number of }\right. \\
\text { workers) } \\
(\mathrm{N}=142) \\
\end{array}$ & $\begin{array}{c}\text { Water } \\
\text { consumption } \\
\left(\mathbf{m}^{3} / \mathbf{m}^{2}\right) \\
(\mathbf{N}=\mathbf{8 0})\end{array}$ & $\begin{array}{c}\text { Energy } \\
\text { consumption } \\
\left(\mathbf{k W h} / \mathbf{m}^{2}\right) \\
(\mathbf{N}=78)\end{array}$ & $\begin{array}{c}\text { Waste } \\
\text { generation } \\
\left(\mathbf{m}^{3} / \mathbf{m}^{2}\right) \\
(\mathbf{N}=63)\end{array}$ \\
\hline Minimum & 0.01 & 0.11 & 0.01 & 0.003 & 0.15 & 0.03 \\
\hline Mean & 3.82 & 48.65 & 3.23 & 0.33 & 5.75 & 0.15 \\
\hline Median & 1.86 & 33.29 & 0.86 & 0.28 & 4.58 & 0.12 \\
\hline $\begin{array}{l}\text { Standard } \\
\text { deviation }\end{array}$ & 12.26 & 69.38 & 17.20 & 0.23 & 4.63 & 0.12 \\
\hline $\begin{array}{l}\text { Variance } \\
\text { coefficient }\end{array}$ & $321 \%$ & $143 \%$ & $532 \%$ & $70 \%$ & $81 \%$ & $79 \%$ \\
\hline $\begin{array}{l}1^{\text {st }} \text { quartile } \\
(\mathrm{Q} 25)\end{array}$ & 0.91 & 15.31 & 0.44 & 0.17 & 2.31 & 0.07 \\
\hline $\begin{array}{l}3^{\text {rd }} \text { quartile } \\
(\mathrm{Q} 75)\end{array}$ & 3.22 & 60.51 & 1.47 & 0.44 & 7.89 & 0.20 \\
\hline $\begin{array}{l}\text { Asymmetry } \\
\text { coefficient }\end{array}$ & 0.18 & 0.20 & 0.20 & 0.19 & 0.19 & 0.32 \\
\hline Maximum & 348.94 & 1512.00 & 440.00 & 1.12 & 21.44 & 0.64 \\
\hline
\end{tabular}


Table 8 - Minimum and maximum performance values

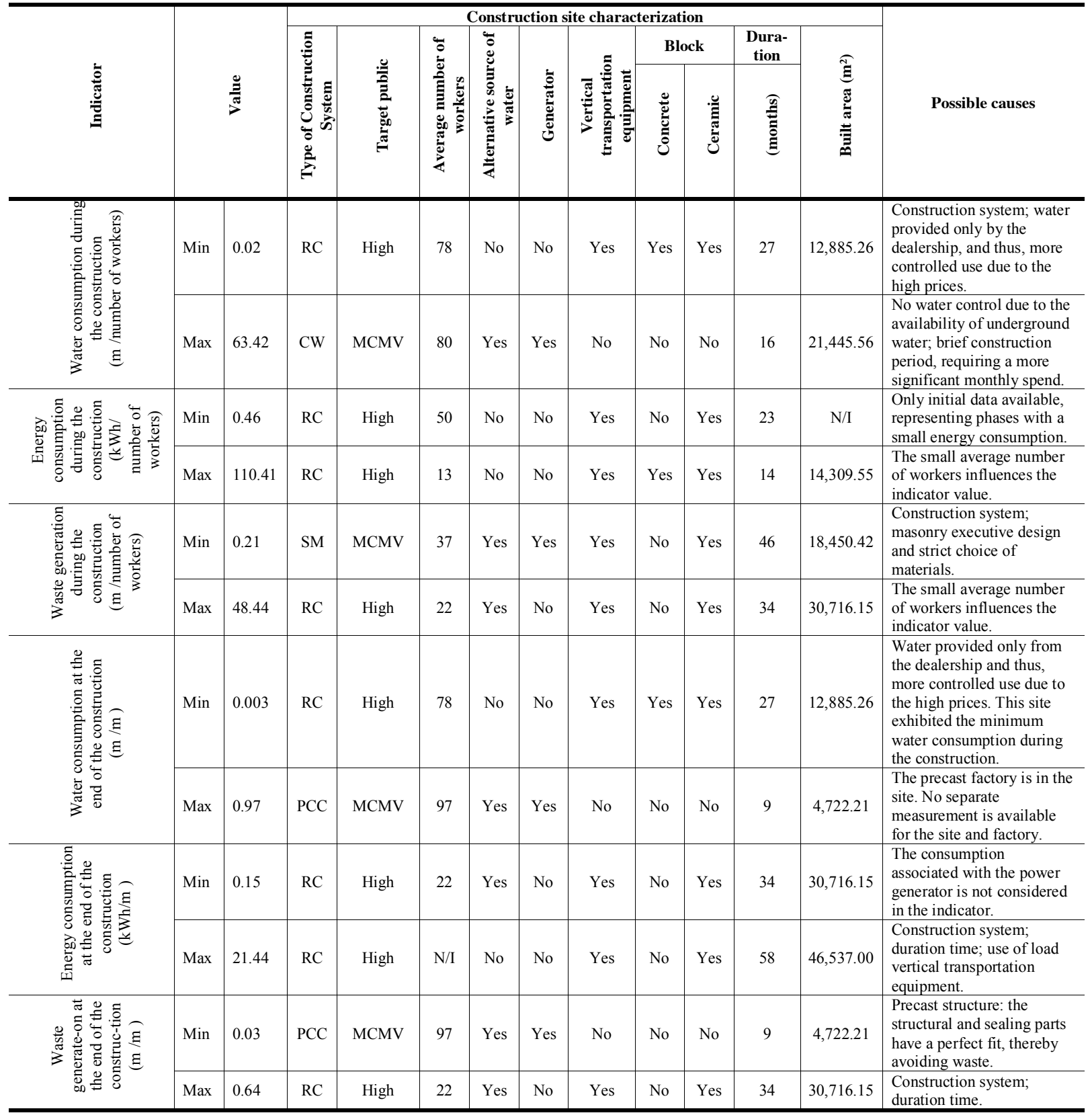

Note:

Min = Minimum;

Max = Maximum;

$\mathrm{RC}=$ Reinforced concrete structure;

$\mathrm{CW}=$ Cast-in-place reinforced concrete wall;

$\mathrm{SM}=$ Structural masonry;

PCC = Precast concrete structure;

MCMV = Brazilian government housing program; and

$\mathrm{N} / \mathrm{I}=$ No information

Figure 2 presents the evolution of the medians for the different years for the following indicators: water consumption during the construction ( $\mathrm{m}$ /number of workers), energy consumption during the construction $(\mathrm{kWh} /$ number of workers), and waste generation during the construction (m /number of workers).

The water consumption graph exhibits a peak value in 2014. However, a downward trend can be observed in the median values of the following years, except from 2016 to 2017. From 2016 to 2018, the annual medians are below the global median.

16 Fernandes, L. L. de A.; Costa, D. B. 
Figure 2 - Medians of the environmental indicators during the construction for different years

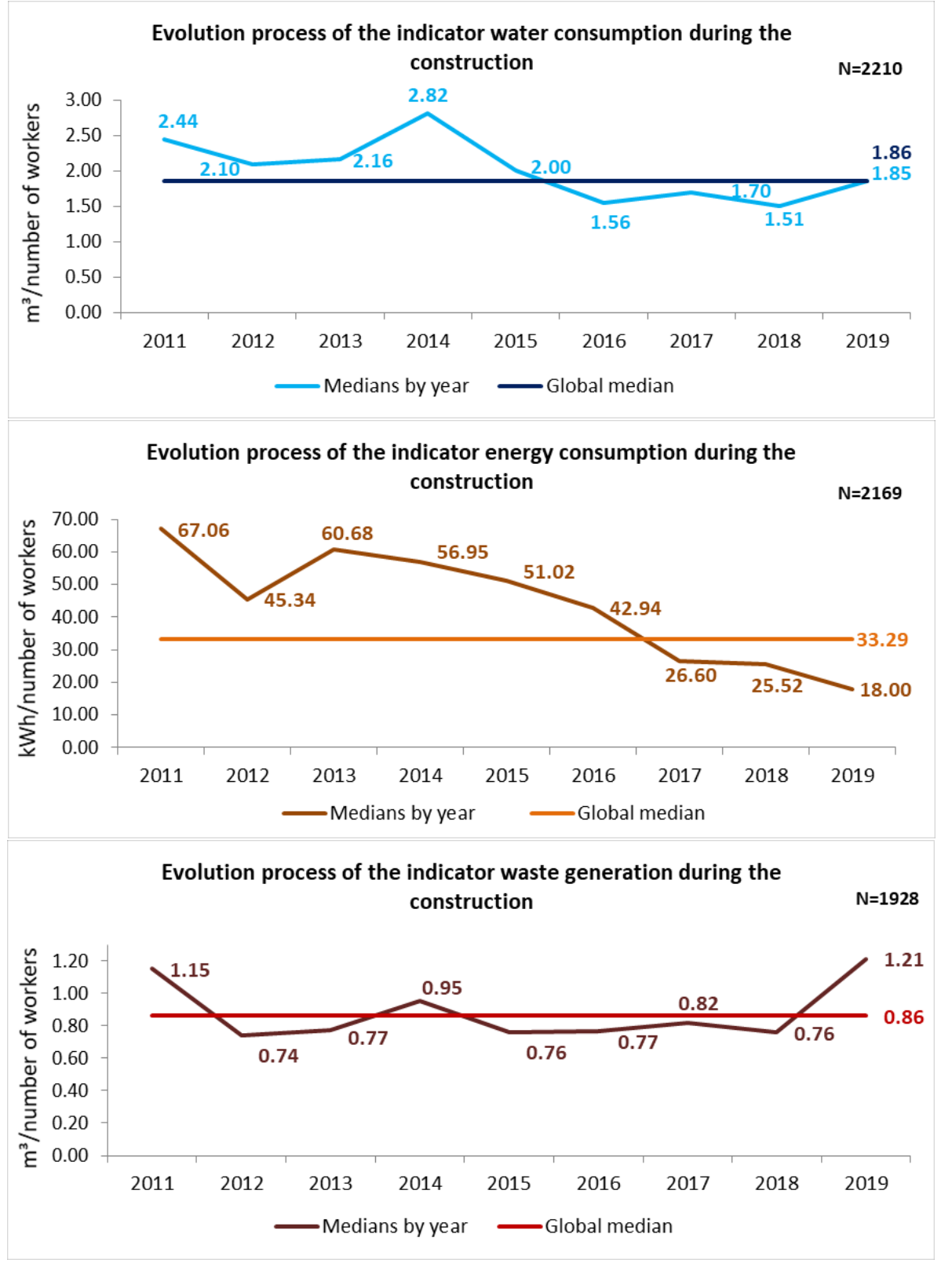

The energy consumption graph presents a clear downward trend for the energy consumption during the construction, especially from 2013 to 2018 , with a reduction of approximately $57.94 \%$ in the indicator median. The highest median value occurred in 2011, likely due to the small amount of data obtained for that year, owing to which, this specific sample is not highly representative. Moreover, since 2017, the annual median values are below the global median.

Both the water and energy consumption indicators presented a downward trend, which highlights the importance of developing a unified performance indicator system. When the indicator collection became mandatory, the companies started exhibiting better results and attempted to reduce their water and energy consumption. During the onsite data collection, several managers stated that they began considering the indicator value of the previous month as a goal for the next month. Therefore, even without consistent targets, the medians exhibited an improved trend.

The annual medians of the waste generation during the construction varied close to the global medians from 2012 to 2018. The median of the 2019 indicator exhibited the highest value; however, as mentioned previously, as this value corresponded to partial data collected until August 2019, the value may change 
when considering a broader sample. One of the reasons for these findings can be the strict regulation imposed by the governments on the waste disposal in Brazil. Most of the cities implement laws and ordinances with severe punishments, such as fines, for improper waste management. Moreover, garbage disposal companies charge a high price to perform these services, and the construction companies are attempting to generate less waste and reuse as much waste as possible onsite.

\section{Hypotheses test}

Table 9 presents the results obtained by conducting hypotheses tests in each stratification of the sample. The following section discusses these results.

\section{Analysis of the type of construction system}

This analysis was aimed at verifying if the construction system influenced the water consumption, energy consumption, and waste generation at the construction sites and to evaluate the corresponding causes.

Figure 3 presents the median value obtained from the sample stratification according to the type of construction systems, in comparison to the global median presented in Table 7.

\section{Water consumption indicators for the different types of construction systems}

In terms of the water consumption, the medians for the structural masonry projects presented the highest values for both the indicators $(2.37 \mathrm{~m} /$ number of workers and $0.32 \mathrm{~m} / \mathrm{m})$. The reinforced concrete structure projects and cast-in-place reinforced concrete wall projects presented the smallest median for the indicator during the construction $(1.67 \mathrm{~m} /$ number of workers $)$ and the indicator at the end of the construction $(0.18 \mathrm{~m} / \mathrm{m})$, respectively (Figure 3$)$.

The hypotheses test results for the three groups and between the reinforced concrete structure and structural masonry projects indicated a significant difference only for the indicators during the construction (Table 9). Since the difference was significant only for the indicators during the construction, a possible cause for the high values associated with the structural masonry projects is the slight difference in the monthly average number of workers, which is smaller than that for the other construction systems projects. However, the difference is small, and this cause could not be statistically proved in this study; therefore, managers must be more careful with the water consumption in structural masonry building projects.

The duration of construction and built area variables were tested as causes for the results. However, the results indicated that no significant difference exists and that these variables do not impact the water consumption indicators (Table 9).

\section{Energy consumption indicators for the different types of construction systems}

The indicators associated with the energy consumption presented the same trends, because the highest medians were associated with the reinforced concrete structure projects $(43.74 \mathrm{kWh} /$ number of workers and $6.73 \mathrm{kWh} / \mathrm{m})$, followed by those of the structural masonry projects $(37.5 \mathrm{kWh} /$ number of workers and 3.77 $\mathrm{kWh} / \mathrm{m})$. The cast-in place reinforced concrete wall projects presented the lowest values (15.21 $\mathrm{kWh} /$ number of workers and $1.86 \mathrm{kWh} / \mathrm{m}$ ) (Figure 3).

The hypotheses test results indicated a significant difference in the energy consumption indicators for the three systems, between the cast-in-place reinforced concrete wall and reinforced concrete structure projects, and the cast-in-place reinforced concrete wall and structural masonry projects (Table 9). The fact that the indicators (with different metrics) presented the same result in the hypotheses tests may indicate the presence of a well-defined standard for the energy consumption of these construction systems.

The use of load vertical transportation equipment and duration of construction variables were tested as causes for the results. As identified in the characterization data from the considered projects, the structural masonry and reinforced concrete buildings were approximately $21.19 \%$ and $75.3 \%$ taller than the cast-inplace reinforced concrete wall ones, respectively. In addition, the reinforced concrete projects were $23 \%$ and $50 \%$ longer than structural mansory and cast-in-place reinforced concrete wall projects, respectively.

18 Fernandes, L. L. de A.; Costa, D. B. 
Table 9 - Results of the hypotheses tests (adopted level of significance $a=5 \%$ )

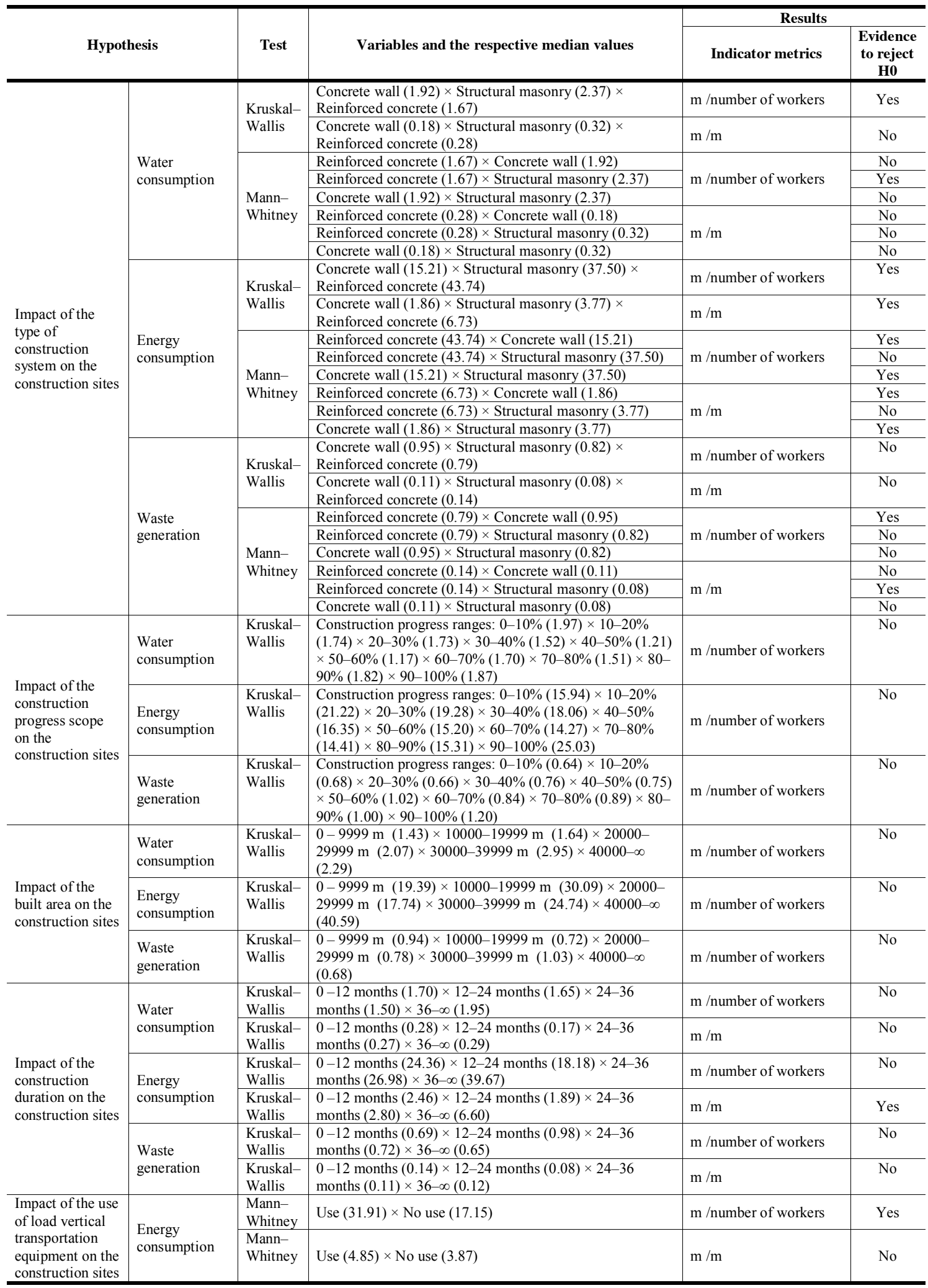


Figure 3 - Median results pertaining to the types of construction systems

Indicators during the construction
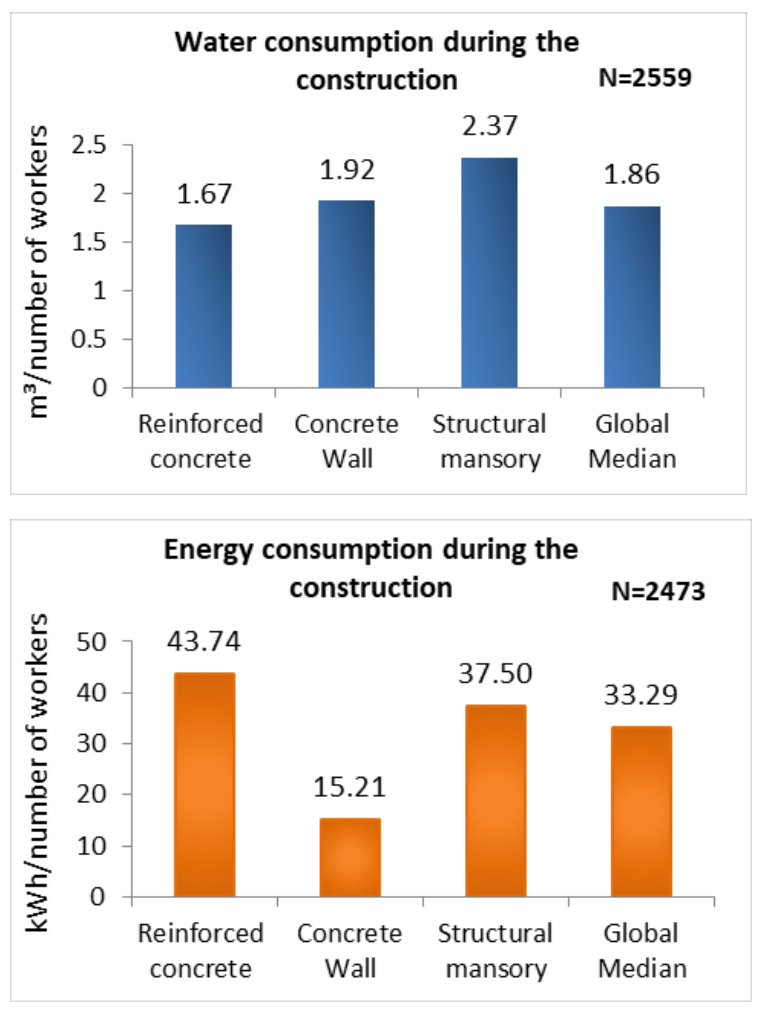

Waste generation during the construction

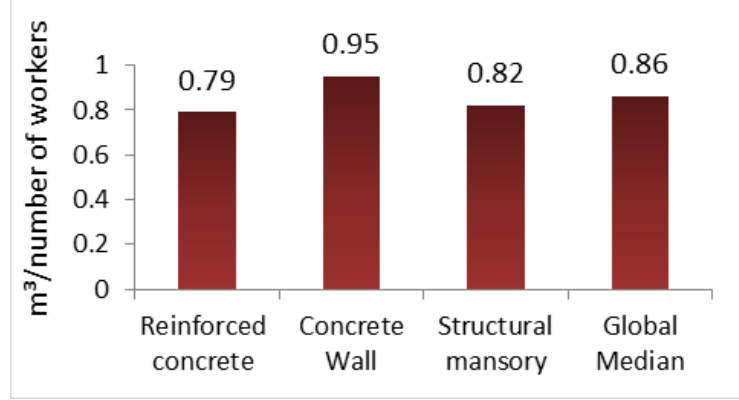

Indicators at the end of the construction

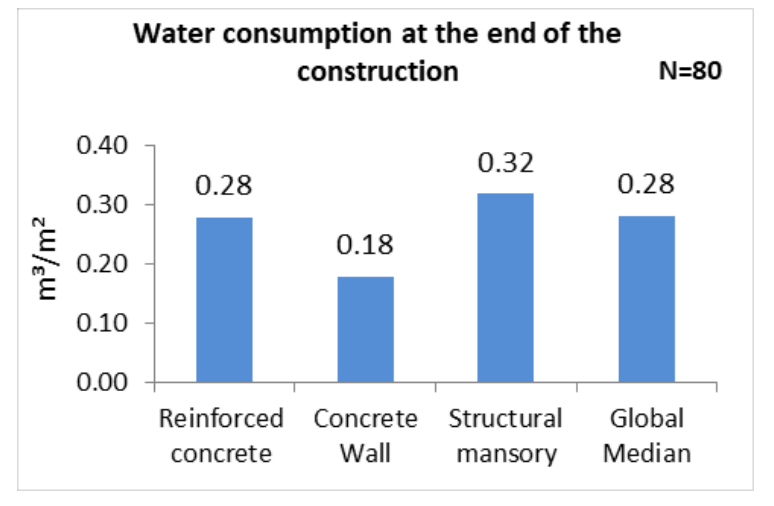

Energy consumption at the end of the construction

$\mathrm{N}=78$
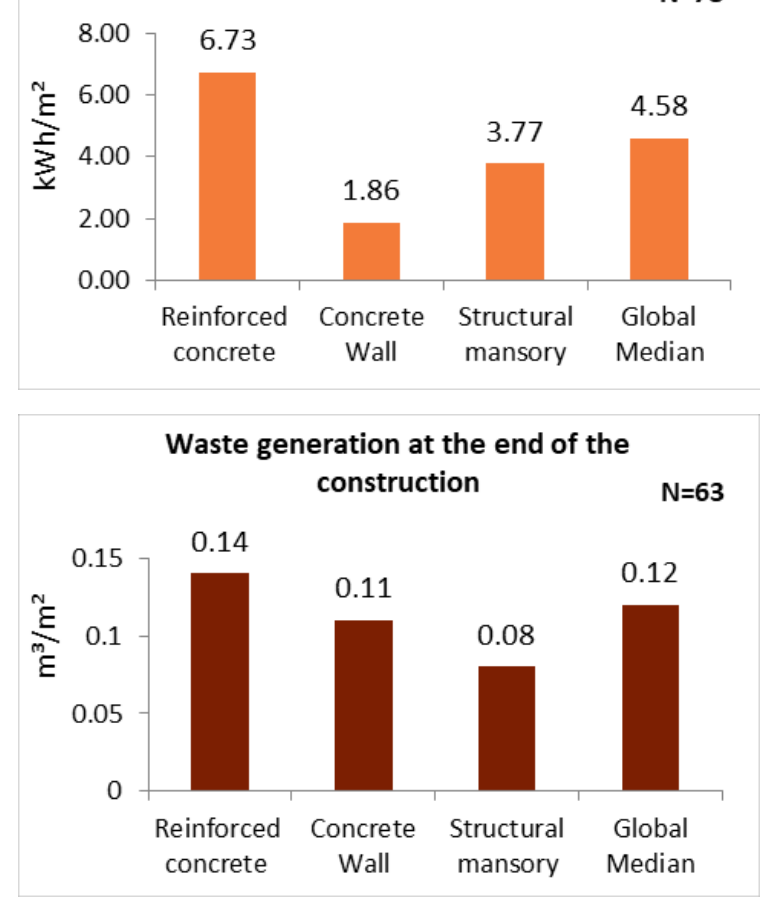

The hypotheses tests indicated that a significant difference existed between the groups that used and did not use load vertical transportation equipment, in terms of the indicator during the construction, and between the groups with different construction durations, in terms of the indicator at the end of the construction. Thus, the use of load vertical transportation equipment influenced the monthly energy consumption of the projects. Although the duration of the construction did not impact the monthly consumption, it influenced the total consumption of the construction period (Table 9).

Furthermore, the variable built area was tested as a cause for the results. The test results indicated no significant difference, and thus, this variable did not impact any of the energy consumption indicators (Table 9).

\section{Waste generation indicators for the different types of construction systems}

The results of the indicators associated with waste generation did not present clear trends. The highest and lowest values for the indicator during the construction corresponded to the cast-in-place reinforced concrete wall system projects $(0.95 \mathrm{~m} /$ number of workers $)$ and reinforced concrete structure system projects $(0.79$ $\mathrm{m}$ /number of workers), respectively. The highest and lowest medians for the indicator at the end of the 
construction corresponded to the reinforced concrete structure system projects $(0.14 \mathrm{~m} / \mathrm{m})$ and structural masonry projects $(0.08 \mathrm{~m} / \mathrm{m})$, respectively (Figure 3$)$.

The Kruskal-Wallis test indicated no significant difference in the waste generation among the construction system projects for any of the indicators. However, the Mann-Whitney U test results indicated a significant difference among the reinforced concrete structure and cast-in-place reinforced concrete wall projects during the construction and reinforced concrete structure and structural masonry projects at the end of the construction (Table 9).

The reduced waste generation of structural masonry projects was not predictable because of the large number of blocks. In non-structured interviews, the managers mentioned that they are managing the waste and investing in more strategies to avoid losses, such as executive design and strict quality control for the block suppliers.

The duration of construction variable was tested to analyze its influence on the waste generation indicators. As mentioned previously, according to the collected data, the reinforced concrete projects were $23 \%$ and $50 \%$ longer than structural mansory and cast-in-place reinforced concrete wall projects, respectively. Therefore, the projects that involved a cast-in-place reinforced concrete wall system likely generated more waste each month because more services occurred simultaneously; however, at the end of the construction phase, due to the larger period, the volume of waste generated by the other construction systems was likely larger. Nevertheless, the hypothesis test results did not indicate a significant difference, and thus, the construction duration did not influence the indicators associated with waste generation.

Furthermore, the built area was tested as a cause for the results. The test results indicated no significant difference, and thus, this variable did not impact any of the waste generation indicators (Table 9).

\section{Analysis of the construction progress scope}

This analysis was aimed at identifying the construction phases that considerably influenced the indicators of water consumption, energy consumption, and waste generation during the construction, to allow the establishment of performance improvement targets considering the needs of each construction stage.

For this analysis, the sample was divided into ten ranges of $10 \%$. The corresponding medians of the indicators during the construction were calculated for each range. Figure 4 presents the graphs with the medians of the three indicators during the construction, calculated for each range of $10 \%$.

The analysis results for the construction phases with the highest and lowest indicator values are as follows.

The medians for the water consumption indicator range from 1.17-1.97 m/number of workers. The highest values are associated with the $0-10 \%$ and $90-100 \%$ ranges of the construction progress, likely owing to the small number of workers in these stages, as well as the conduction of earthwork services, final cleaning, and tightness tests. The lowest median is in the 50-60\% range, which, based on the characterization data obtained in this study, is generally related to the structure phase. It must be noted that the structures for $89 \%$ of the buildings for the considered sample are constructed mainly using reinforced concrete (except structural masonry), which is transported to the site ready for use; therefore, the associated water is not considered in the indicator.

The energy consumption indicator exhibits values ranging from $14.27-25.03 \mathrm{kWh} /$ number of workers. The lowest value corresponds to the $60-70 \%$ range, as the use of certain equipment is reduced in the final stages of the structure construction. The highest value is $25.03 \mathrm{kWh} /$ number of workers, in the $90-100 \%$ range, likely owing to the construction finalization and conduction of equipment tests.

The medians for the waste generation indicators ranged from 0.64-1.20 m/number of workers, for the ranges of $0-10 \%$ and $90-100 \%$, respectively. The lowest value occurs at the beginning of the construction, when most activities are associated with soil adjustments, and the indicator does not consider the soil in the calculation. The indicator presents an increasing trend, indicating that the amount of waste increases as the construction progress advances and the construction phase ends. The highest value, corresponding to the last range, is likely associated with the construction site demobilization and cleaning and with the reduction of the number of workers.

The Kruskal-Wallis test indicated no significant difference among the groups for the three indicators (Table 9). Therefore, the impacts associated with the water consumption, energy consumption, and waste generation do not exhibit significant differences among the construction phases. 
Figure 4 - Results corresponding to the construction progress

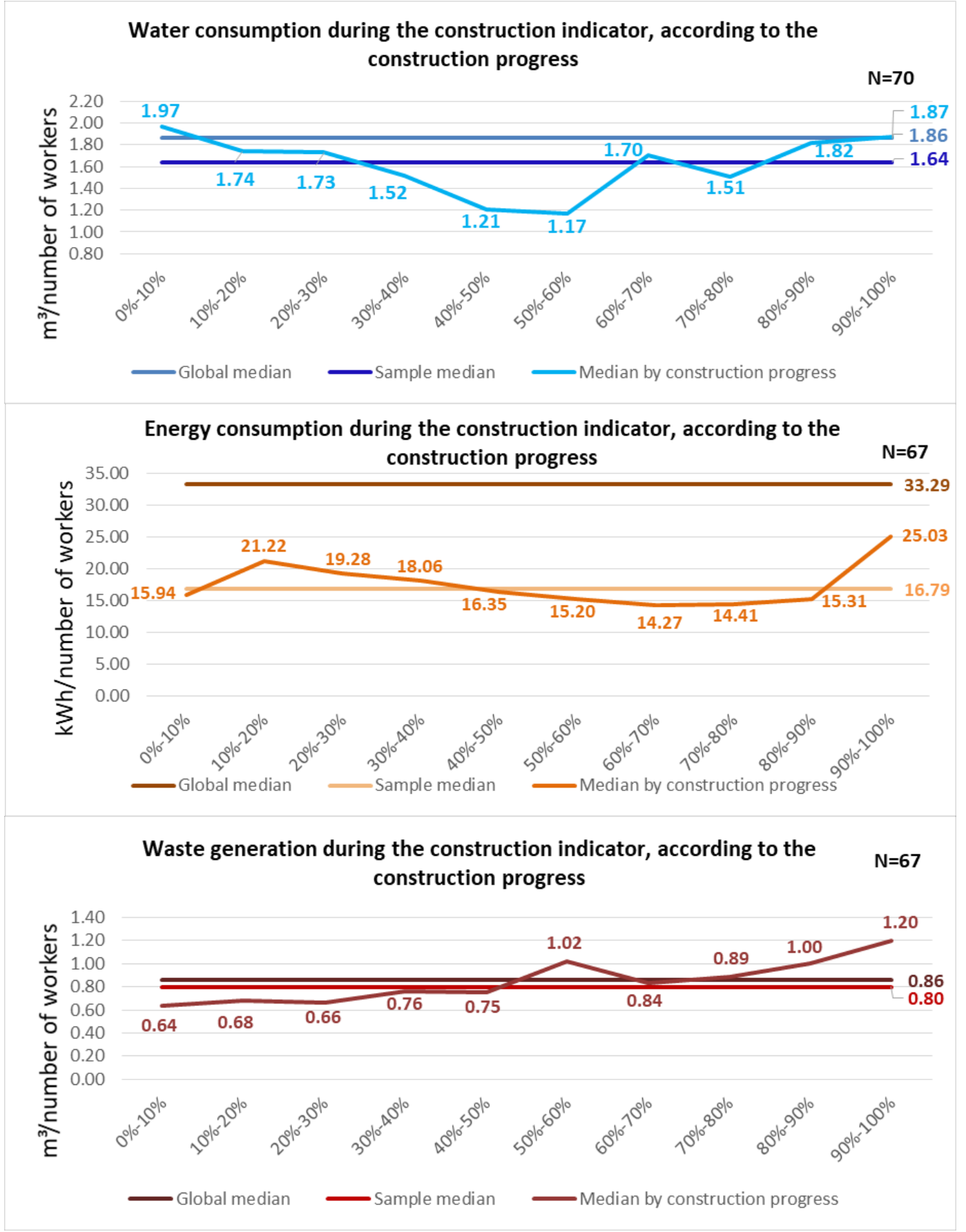

Even though the hypothesis test did not highlight any significant differences in the indicators among the construction phases, to enhance the environmental performance of building construction, the managers must be aware of the site impact for each phase to identify any specific problems, outline the relevant strategies, and implement mitigating measures.

\section{Discussion}

The results of this study demonstrated the importance of developing a unified environmental indicator system that can enable the collection of standard metrics among construction projects, thereby facilitating the assessment and analysis of the scenario and evolution of the building construction environmental performance.

22 Fernandes, L. L. de A.; Costa, D. B. 
Many indicators for the environmental performance have been proposed, and, in general, the construction companies choose the measures that are relevant to their business. However, without a unified set of metrics, benchmarking and the sharing of information pertaining to consistent target achievement and best practices cannot be realized. Consequently, the establishment of indicators by the PBQP-H Program is an essential initiative.

Although the sample of this study is small (186 projects and 9,156 data) compared to the overall building sector, the similarities identified among the data and the statistical evidence obtained in the hypotheses tests indicate a specific pattern, especially when comparing construction projects with the same construction system. The findings indicate that, by using an expanded sample, the data may present a similar pattern in the context of the considered project construction systems.

The evolution process analysis indicated reduced median values for the water and energy consumption indicators during the construction as the years advanced. From 2011 to 2019, the results were notably improved, emphasizing the importance of implementing a performance measurement system for continuous improvement. The mandatory collection of the indicator values helped examine the environmental performance in the construction sites and identify the possible actions to reduce the water and energy consumption during the construction. Nonetheless, benchmarking is particularly important in the continuous improvement process. The establishment of reference values can help the companies improve their indicators values as the managers can reestablish the targets and implement proper actions.

The findings indicated that the type of construction system exhibited considerable differences in the samples. In the considered scenario, the cast-in-place reinforced concrete wall projects exhibited a higher performance than reinforced concrete structure and structural masonry projects. The best outcome corresponded to the energy consumption indicators, in which the cast-in-place reinforced concrete wall projects presented a significant difference; however, the difference between this system and the other systems was small in the case of the water consumption and waste generation indicators. This result was expected, because the purpose of this system is to execute more repetitive and industrialized construction activities, thereby reducing the learning curve and increasing the standardization of the processes. Moreover, cast-in-place reinforced concrete wall systems are generally associated with low income housing projects, having little or no variability among the housing units. The reinforced concrete structure system, in general, is used for residential and commercial high rise buildings targeting high income public, thereby involving complexities in terms of the variability and customization.

Based on the non-structured interviews conducted with managers and discussions conducted with the academic community during the research, the use of the PBQP-H indicators during the construction as key environmental performance measures was considered to be debatable as the indicators consider the number of workers as a variable. At the end of 2018, the PBQP-H Program removed some indicators from the mandatory list and retained only the indicators at the end of the construction. However, this action is associated with certain concerns.

It must be noted that the indicators during the construction and at the end of the construction are leading and lagging indicators, respectively. Leading indicators enable the anticipation and resolution of problems, thereby enabling any necessary interventions in the process, for improvement and control (HNOREC, $1994^{1}$ apud LANTELME, 1994). The lagging indicators assess the fulfillment of the company's goals (COSTA et $a l ., 2005)$. Thus, the indicators during the construction can help the managers understand the site impacts throughout the process, thereby enabling continuous improvement.

Moreover, the existing literature reports on the adoption of certain indicators related to the water consumption, energy consumption, and waste generation in different national initiatives (Table 1), despite the differences among the metrics. In Brazil, the measurement of the water consumption, energy consumption, and waste generation (or any other environmental indicator) related to the project cost, as suggested by Constructing Excellence (2016) and Hastak et al. (2017), may lead to several misinterpretations. For example, low cost projects (as low income housing projects) and high cost projects may exhibit high and low indicator values, respectively, and these values may not reflect the real impact of the construction project. Thus, the metric definition must consider the needs of the internal regions or the contexts of different countries.

${ }^{1}$ HNOREC, S. Usando medidas do desempenho da qualidade, tempo e custo para traçar a rota para o futuro de sua empresa. São Paulo: Makron Books, 1994. 
In addition, this study, focused on the PBQP-H indicators during the construction, provided evidence regarding the trends of the environmental performance of the building sector. Even though the Brazilian construction sector is undergoing increased industrialization, the amount of workforce required in the traditional construction systems has not changed considerably, as indicated by the average number of workers not being significantly different among the considered construction systems. Therefore, the indicators during the construction are important to improve the environmental performance in the building construction sector.

\section{Conclusions}

This research aimed to evaluate the scenario and evolution of the environmental performance of building construction sites, based on the PBQP-H indicators. The analysis highlighted the importance of establishing an environmental performance measurement system, as the data for the different years exhibited a decrease in the indicator values for water and energy consumption.

The studied hypotheses and causes, analyzed through the Kruskal-Wallis and Mann-Whitney tests, indicated that the type of construction system exhibited significant differences in the samples, although the difference among the construction phases was not significant. Nevertheless, identifying the stages with the smallest and largest indicator values can help clarify the impacts and facilitate the decision making process for mitigating actions.

The main theoretical contribution of this study is the environmental performance analysis, which provides reference values for the whole sample, considering the year, type of construction system, and construction progress scopes, thereby allowing the establishment of a preliminary scenario for building projects during the construction phase. In this study, the medians of each sample were selected as the reference values to minimize the impact of the complexity and variability of the construction processes on the value. The main practical contribution is the developed database with reference values, which can be used by organizations to facilitate performance improvements and by the academia as a base for future research.

To enable a more comprehensive analysis of the environmental performance of building construction, it is necessary to expand the proposed database and to collect indicators that encompass other aspects of sustainability dimensions (social, economic, and environmental). Moreover, although the values provided in this study can be used as target values, it is necessary to realize a widespread application of these references and expand database to establish an acceptable range of numbers in which each indicator can be fit. Sectoral and governmental entities can use the established database to analyze the performance evolution of the building construction market niche in terms of the environmental aspects and trace the trends to formulate public policies. Furthermore, the academia can use these reference values as a starting point for future research related to building construction environmental performance improvements, for instance, to extend the developed database, propose mitigating actions, and evaluate other environmental indicators and metrics.

The government and sectorial entities can use the data of this study as the first step to develop a national platform of sustainability indicators for building construction, in which companies can share and benchmark their performances. The platform is expected to be a free, collaborative, and online system, involving the indicator reference values for consultation, and enabling the companies to anonymously share information. In this manner, the building construction sector can realize benchmarking to improve the relevant performances, and the academia can perform further work based on this data.

\section{References}

ALMEIDA, L. de B.; COSTA, D. B.; ALBERTE, E. P. V. Proposta de sistema de indicadores de desempenho para gestão sustentável em canteiros de obras. Ambiente Construído, Porto Alegre, v. 20, n. 1, p. 153-170, jan./mar. 2020.

AUSTRALIA. Forest and wood products research and development corporation. Technical Evaluation of Environmental Assessment Rating Tools. Australia, 2005.

CHAN, Y.; WALMSLEY, R. P. Learning and understanding the kruskal-wallis one-way analysis-ofvariance-by-ranks test for differences among three or more independent groups. Physical Therapy, v. 77, n. 12, p. 1755-1761, 1997. 
CONSTRUCTING EXCELLENCE. UK Industry Performance Report 2016. 2016. Available in: https://constructingexcellence.org.uk/wpcontent/uploads/2018/11/UK_Industry_Performance_Report_2016_LR.pdf. Access: 15 Aug. 2019.

COSTA, D. B. et al. SISIND-NET - Sistema de indicadores para Benchmarking na construção civil: manual de utilização. Porto Alegre: UFRGS/PPGEC/NORIE, 2005.

COSTA, D. et al. Benchmarking Initiatives in the Construction Industry: lessons learned and improvement opportunities. Journal of Management in Engineering, v. 22, n. 4, 2006.

EL-MASHALEH, M. S.; MINCHIN JUNIOR, R. E.; O'BRIEN, W. J. Management of construction firm performance using Benchmarking. Journal of Management in Engineering, v. 23, n. 1, p. 10-17, 2007.

FERNANDES, L.; ROCHA, M.; COSTA, D. Uso do clustering para análise do impacto do sistema construtivo no consumo de água, consumo de energia e geração de resíduos de canteiro de obras. In: ENCONTRO NACIONAL DE TECNOLOGIA DO AMBIENTE CONSTRUÍDO, 18., Porto Alegre, 2020. Proceedings [...] Porto Alegre: ANTAC, 2020.

FUERTES, A. et al. An environmental impact causal model for improving the environmental performance of construction processes. Journal of Cleaner Production, v. 52, p. 425-437, 2013.

GANGOLELLS, M. et al. Analysis of the implementation of effective waste management practices in construction projects and sites. Resources, Conservation and Recycling, v. 93, p. 99-111, 2014.

GUIMARÃES, M. S. O. Diretrizes para desenvolvimento de canteiro de obras habitacional de baixo impacto ambiental. Salvador, 2013. Dissertação (Mestrado em Engenharia Ambiental Urbana) - Mestrado em Engenharia Ambiental Urbana, Universidade Federal da Bahia, Salvador, 2013.

HASTAK, M. et al. KPI and Trends Committee Progress. 2017. 38 slides.

HOFFENSON, S.; DAGMAN, A.; SODERBERG, R. A multi-objective tolerance optimization approach for economic, ecological, and social sustainability. In: NEE, A.; SONG, B.; ONG, S. K. Reengineering Manufacturing for Sustainability. Singapore: Springer, 2013.

ILHAN, B; YOBAS, B. Measuring construction for social, economic, and environmental assessment. Engineering, Construction and Architectural Management, v. 26, n. 5, p.746-765, 2019.

JIANG, Q. et al. A principal component analysis based three-dimensional sustainability assessment model to evaluate corporate sustainable performance. Journal of Cleaner Production, v. 187, p. 625-637, 2018.

LANTELME, E. Proposta de um sistema de indicadores de qualidade e produtividade para a construção civil. Porto Alegre, 1994. Dissertação (Mestrado em Engenharia) - Núcleo Orientado para a Inovação da Edificação, Programa de Pós-graduação em Engenharia Civil, Universidade Federal do Rio Grande do Sul, Porto Alegre, 1994.

LÓPEZ, F.R.; SÁNCHEZ, G. F. Challenges for sustainability assessment by indicators. Leadership and Management in Engineering, v. 11, p. 321-325, 2011.

MCKIGHT, P. E.; NAJAB, J. Kruskal-Wallis Test. In: WEINER, I. B.; CRAIGHEAD, W. E. The Corsini Encyclopedia of Psychology. Hoboken: John Wiley \& Sons, 2010a.

MCKIGHT, P. E.; NAJAB, J. Mann-Whitney U Test. In: WEINER, I. B.; CRAIGHEAD, W. E. The Corsini Encyclopedia of Psychology. Hoboken: John Wiley \& Sons, 2010b.

MINISTÉRIO DAS CIDADES. Secretaria Nacional de Habitação. Programa Brasileiro da Qualidade e Produtividade do Habitat - PBQP-H - Sistema de Avaliação da Conformidade de Empresas de Serviços e Obras da Construção Civil - SiAC. Brasília, 2018.

MOULLIN, M. Performance measurement definitions. International Journal of Health Care Quality Assurance, v. 20, n. 3, p. 181-183, 2007.

NACHAR, N. The Mann-Whitney U: a test for assessing whether two independent samples come from the same distribution. Tutorials in Quantitative Methods for Psychology, v. 4, n. 1, 2008.

NAPPI, V.; ROZENFELD, H. The incorporation of sustainability indicators into a performance measurement system. Procedia CIRP, v. 26, p. 7-12, 2015.

NEELY, A. et al. Design performance measure: a structure approach. International Journal of Operation \& Production Management, Bradford, v. 17, n. 11, p. 1131-1152, 1997. 
OLIVEIRA, J. A. C. Proposta de avaliação e classificação da sustentabilidade ambiental de canteiros de obras. Metodologia ECO OBRA aplicada no Distrito Federal - DF. Brasília, 2011. Tese (Doutorado em Engenharia Civil) - Departamento de Engenharia Civil e Ambiental, Universidade de Brasília, Brasília, 2011.

ORTIZ, O.; PASQUALINO, J. C.; CASTELLS, F. environmental performance of construction waste: comparing three scenarios from a case study in Catalonia, Spain. Journal of Waste Management, v. 30, n. 4, p. 646-654, 2010 .

REZAEI, A. R.; ÇELIK, T.; BAALOUSHA, Y. Performance measurement in a quality management system. Scientia Iranica, v. 18, n. 3, p. 742-752, 2011.

SHAHBAZI, S. et al. Material efficiency measurements in manufacturing: Swedish case studies. Journal of Cleaner Production, v. 181, p. 17-32, 2018.

SIGURJÓNSSON, J. et al. Environmental indicators for the construction and property sector. In: INTERNATIONAL CONFERENCE OF SUSTAINABLE BUILDING, Oslo, 2002. Proceedings [...] Oslo: EcoBuild, 2002.

SILVA, V. G. Avaliação da sustentabilidade de edifícios de escritórios brasileiros: diretrizes e base metodológica. São Paulo, 2003. 210 f. Tese (Doutorado em Engenharia Civil) - Escola Politécnica, Universidade de São Paulo, São Paulo, 2003.

SILVA, V. G. Indicadores de sustentabilidade de edifícios: estado da arte e desafios para desenvolvimento no Brasil. 2007. Ambiente Construído, Porto Alegre, v. 7, n. 1, p. 47-66, jan./mar. 2007.

THOMAS, N. I. R.; COSTA, D. B. Adoption of environmental practices on construction sites. Ambiente Construído, Porto Alegre, v. 17, n. 4, p. 9-24, out./dec. 2017.

WALLBAUM, H. Sustainability indicators for the built environment: the challenges ahead. In: WORLD SUSTAINABLE BUILDING CONFERENCE, Melbourne, 2008 Proceedings [...] Melbourne: CIB, 2008.

\section{Acknowledgements}

The authors acknowledge the grant from the Brazilian Chamber of the Construction Industry (CBIC) for the development of the study. This work was also supported by the Ministry of Education of Brazil through the Agency of Support and Evaluation of Graduate Education (CAPES) with student scholarship support.

\section{Luara Lopes de Araujo Fernandes}

Programa de Pós-Graduação em Engenhara Civil | Universidade Federal da Bahia | Rua Aristides Novis, 2, $8^{\circ}$ andar, Federação | Salvador Bahia - Brasil | CEP 40210-630 | E-mail: luara.fernandes@gmail.com

Dayana Bastos Costa

Departamento de Construção e Estruturas | Universidade Federal da Bahia | Rua Aristides Novis, $2,5^{\circ}$ andar, Federação | Salvador - Bahia - Brasil | CEP 40210-630 | E-mail: dayanabcosta@ufba.br

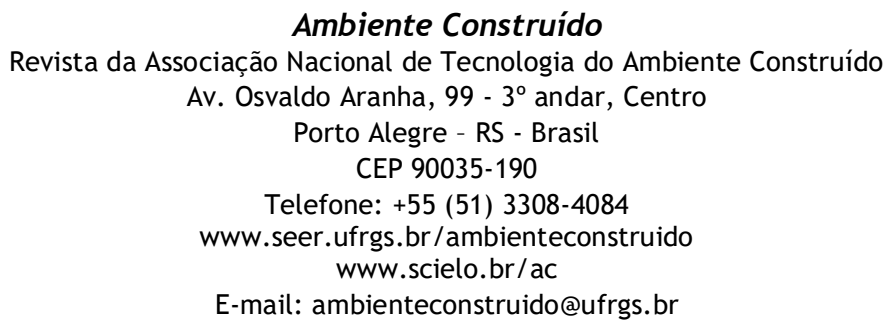

cC) 